\title{
Inflammatory bowel disease in married couples: 10 cases in Nord Pas de Calais region of France and Liège county of Belgium
}

\author{
M C Comes, C Gower-Rousseau, J F Colombel, J Belaïche, H J Van Kruiningen, \\ M C Nuttens, A Cortot
}

Registre des Maladies Inflammatoires du Tube Digestif du Nord Ouest de la France CHRU Lille, France M C Comes C Gower-Rousseau J F Colombel M C Nuttens A Cortot

Service d'HépatoGastroentérologie, CHU Liège, Belgium J Belaïche

Department of Pathobiology, University of

Connecticut, Storrs, USA

H J Van Kruiningen

Correspondence to: Professor J F Colombel, Registre des Maladies Inflammatoires du Tube Digestif du Nord Ouest de la rance, Service d'Hepatogastroenterologie, Hopital Huriez,

Accepted for publication 8 December 1993

\begin{abstract}
Ten pairs of husband-wife couples are reported with inflammatory bowel disease who were seen in the same geographical area in Nord Pas de Calais region of France and in Liege county (Belgium). Among these 10 couples, four were concordant for Crohn's disease, two for ulcerative colitis, and four were discordant. In nine of 10 couples neither spouse had symptoms before marriage but inflammatory bowel disease subsequently developed in both. In one couple, one spouse had Crohn's disease before marriage and the other partner experienced symptoms afterwards. Eighteen children were born to eight of 10 couples. Five of them developed Crohn's disease but four belong to the same family. In all cases the affected children were born to parents who both developed Crohn's disease after they had married and were conceived at a time when parents did not yet have symptoms. It is proposed that this pattern of emergence of inflammatory bowel disease suggests a role for an infectious agent yet to be identified.

(Gut 1994; 35: 1316-1318)
\end{abstract}

TABLE I Onset data for inflammatory bowel disease in spouses

\begin{tabular}{|c|c|c|c|c|c|c|}
\hline & Sex & $\begin{array}{l}\text { Year of } \\
\text { birth }\end{array}$ & $\begin{array}{l}\text { Onset of } \\
\text { disease }\end{array}$ & $\begin{array}{l}\text { Age at } \\
\text { onset }(y)\end{array}$ & $\begin{array}{l}\text { Interval from } \\
\text { marriage to } \\
\text { onset }(y)\end{array}$ & $\begin{array}{l}\text { Type of } \\
I B D\end{array}$ \\
\hline $\mathrm{B} 1$ * & $\begin{array}{l}\mathbf{M} \\
\mathbf{F}\end{array}$ & 1959 & $\begin{array}{l}1974 \\
1984\end{array}$ & 15 & NA & CD \\
\hline $\mathrm{Cl}^{\star}{ }^{\star}$ & $\mathbf{M}$ & 1933 & $\begin{array}{l}1904 \\
1970\end{array}$ & $\begin{array}{l}23 \\
37\end{array}$ & $\begin{array}{r}1 \\
12\end{array}$ & CD \\
\hline & $\mathbf{F}$ & 1938 & 1988 & 50 & 30 & CD \\
\hline $\mathrm{C} 2$ & $\mathbf{M}$ & 1938 & 1980 & 42 & 21 & CD \\
\hline & $\mathbf{F}$ & 1938 & 1990 & 52 & 31 & CD \\
\hline C3 & $\mathbf{M}$ & 1951 & 1992 & 41 & 18 & $\mathrm{CD}$ \\
\hline & $\mathrm{F}$ & 1954 & 1990 & 36 & 16 & CD \\
\hline \multirow[t]{2}{*}{ C4 } & M & 1954 & 1991 & 37 & 7 & CD \\
\hline & $\mathbf{F}$ & 1959 & 1985 & 26 & 1 & UC \\
\hline \multirow[t]{2}{*}{ C5 } & $\mathbf{M}$ & 1927 & 1981 & 54 & 23 & $\mathrm{CD}$ \\
\hline & F & 1926 & 1992 & 66 & 44 & UC \\
\hline \multirow[t]{2}{*}{ C6 } & $\mathbf{M}$ & 1946 & 1983 & 37 & 10 & UC \\
\hline & $\mathbf{F}$ & 1950 & 1975 & 25 & 2 & CD \\
\hline \multirow[t]{2}{*}{ C7 } & $\mathbf{M}$ & 1949 & 1988 & 39 & 9 & CD \\
\hline & $\mathbf{F}$ & 1955 & 1980 & 25 & 1 & UnC \\
\hline \multirow[t]{2}{*}{ C8 } & M & 1947 & 1991 & 44 & 20 & \\
\hline & $\mathbf{F}$ & 1951 & 1979 & 28 & 8 & UC \\
\hline \multirow[t]{2}{*}{ C9 } & M & 1943 & 1992 & 49 & 28 & UC \\
\hline & $\mathbf{F}$ & 1942 & 1973 & 31 & 9 & UC \\
\hline
\end{tabular}

$\star=$ Same family; UC $=$ ulcerative colitis; $\mathrm{CD}=$ Crohn's disease; $\mathrm{UnC}=$ unclassified colitis; NA = not applicable.
Inflammatory bowel disease (IBD) has been ascribed to genetic influences, environmental factors, or a combination of both. The rarity of IBD in married couples has been considered evidence against the importance of environmental factors in the aetiology of the disease. In 1991, however, Bennett et al from New York identified 21 couples with IBD, 14 of whom experienced disease in the second spouse after they were married. ${ }^{1}$ This study brought to 39 the total number of case reports of IBD in husband-wife couples in published works. $^{2-18} \mathrm{We}$ recently described the occurrence of Crohn's disease in a married couple, their four children and the wife of the eldest son. ${ }^{19} \mathrm{We}$ now report an additional eight pairs of husband-wife couples with IBD seen in the same geographical area in Nord Pas de Calais region of France and in the county of Liege (Belgium).

\section{Methods}

This study was realised through the Registre des Maladies Inflammatoires du Tube Digestif du Nord-Ouest de la France ${ }^{20}$ and the Liege county of Belgium. The total population of the geographical area (3966 125 for Nord Pas de Calais and 441125 for Liège County) was surveyed through the gastroenterologists. Each gastroenterologist participating in the study was asked to refer conjugal forms of IBD to an interviewer practitioner. All gastroenterologists were contacted - that is, 155,147 of whom replied $(95 \%)$. All the patients' family data were then collected in a standard form. The following data were gathered: dates of birth, marriage (or cohabitation), onset of symptoms, and diagnosis of IBD; consanguinity; location of residence; dates of birth of all children, type of IBD in parents and children. Diagnosis of IBD was established according to standard criteria. ${ }^{20}$

Couples were assigned to three groups (A, $\mathrm{B}, \mathrm{C})$ paralleling the groups of Bennett et al ${ }^{1}$ based on the time of onset of symptoms of disease in each partner relative to the data of the marriage: A, onset of symptoms occurred before marriage in both; $B$, onset of symptoms occurred in husband or wife after marriage; C, onset of symptoms occurred after marriage in both. 


\section{Results}

Eight couples who both had IBD were identified in Nord Pas de Calais and two in Liège County. None of the couples studied were consanguineous. No couple was assigned to group $\mathrm{A}$, one couple, concordant for Crohn's disease, was assigned to group B, and nine to group $\mathrm{C}$ (Table I). In this group, three couples were concordant for Crohn's disease (C1, C2, C3), two for ulcerative colitis (C8, $\mathrm{C} 9$ ), and four were discordant (C4, C5, C6, C7). The mean age of disease onset was 30 years in the first spouse and 40 years in the second spouse. The first spouse to develop IBD was the husband in four couples $(B 1, C 1$, $\mathrm{C} 2, \mathrm{C} 5)$ and the wife in the remaining six couples. The first spouse to develop IBD had Crohn's disease in six cases. The first spouse developed IBD an average of 9.4 years (1-23) after marriage and the second spouse an average of $10 \cdot 4$ years after the first.

Three of 20 husbands and wives with IBD had a first degree relative with IBD (wives of $\mathrm{C} 1$ and $\mathrm{C} 4$ couples and husband of $\mathrm{B} 1$ couple).

Eighteen children were born to eight of 10 couples (Table II). Among them five developed Crohn's disease, four belonging to the same family. In all cases the affected children were born to parents who both developed Crohn's disease after they had married and were conceived at a time when parents did not yet have symptoms of Crohn's disease.

\section{Discussion}

We report 10 married couples with IBD seen in the same geographical area of northern France and Liège county of Belgium. In nine of 10 couples neither spouse had symptoms before marriage, but IBD subsequently developed in both. In the last case only one spouse had IBD before marriage, and the other partner experienced symptoms afterwards. We found a high rate of IBD ( $28 \%$ ) in the offspring of these couples, close to the $36 \%$ reported by Bennett et al but four of the five children belong to the same extensively described

TABLE II Children borm to parents with inflammatory bowel disease

\begin{tabular}{llll}
\hline & Age $(y) /$ sex & Age at onset & Type of IBD \\
\hline B1 & $6 / \mathrm{M}$ & & \\
& $3 / \mathrm{M}$ & 15 & CD \\
C1 & $34 / \mathrm{M}$ & 9 & CD \\
& $28 / \mathrm{F}$ & 14 & CD \\
& $25 / \mathrm{M}$ & 14 & CD \\
C2 & $24 / \mathrm{F}$ & 18 & \\
C3 & $23 / \mathrm{F}$ & & \\
& $10 / \mathrm{M}$ & & \\
& $11 / \mathrm{M}$ & & \\
C4 & $15 / \mathrm{M}$ & & \\
& $18 / \mathrm{F}$ & & \\
C5 & 4/F & & \\
C6 & NA & & \\
& $16 / \mathrm{M}$ & & \\
C7 & $18 / \mathrm{F}$ & & \\
C8 & NA & & \\
C9 & $19 / \mathrm{M}$ & & \\
& $20 / \mathrm{F}$ & & \\
\hline
\end{tabular}

$\mathrm{NA}=$ not applicable family with remarkably similar Crohn's disease. ${ }^{19}$

Although improbable, we cannot confirm that these marital clusterings did not occur by chance. Using prevalence data of IBD in published works, Lobo et al and Bennett et al calculated that the occurrence of marital Crohn's disease in the United Kingdom and marital IBD in the United States was greater than expected by chance. No such calculation was possible in our study as the prevalence of IBD in France and Belgium is still unkown.

None of the couples were consanguineous and all were white thus avoiding the possible bias of unknown genetic links in our patients, as in Jews. Our series of marital IBD is thus certainly not suggestive of an inherited disease. On the contrary it may reflect an increase in environmental risk in the home. The mean interval between onset of disease in spouses was 10.4 years. A similar long latent period between new cases has been seen in other clusters of IBD. In one series of marital IBD the latent period was 6.4 years in group $B$ and 6.8 years in group C. ${ }^{1}$ In the other series, the latent period was $7 \cdot 2$ years (all couples belonging to group C). ${ }^{4}$ Clustering of cases of IBD among unmarried subjects has also been described. In 1986, Reilly and Robinson, from Northern Ireland, described four cases of Crohn's disease in unrelated adult women, ages 21-30, who had been close high school associates for seven years, from the ages of 11 to $18 .{ }^{21}$ Allan et al described a clustering of 12 patients with Crohn's disease in Gloucestershire, England. ${ }^{22}$ The latent period for Crohn's disease after leaving the community was three to five years. More recently Aisenberg et al described three unrelated men who enjoyed a close sustained friendship in college and who developed symptoms three, five, and nine years after the beginning of their contact. ${ }^{23}$ We think that the pattern of emergence of IBD in our study and in these cases, suggests a role for an infectious agent yet to be identified.

We thank Drs Devred, Prades, Lefebvre, Silvie, Marti, Martin, Ostyn, Fontaine, Lemaire, and Lemahieu for their participation in the study. This work has been presented in part at the 16th Journées Francophones d'Hépatogastroentérologie (March 1992, Paris) and was supported by the Association F Aupetit, the Caisse Régionale d'Assurance Maladie de Nord-Picardie, the Ministère de la Santé et de l'Action Humanitaire (Direction Générale de la Santé), the INSERM, and Ferring Company.

1 Bennett RA, Rubin PH, Present DH. Frequency of inflammatory bowel disease in offspring of couples both presenting with inflammatory bowel disease. Gastroenterology 1991; 100: 1638-43.

2 Kirsner JB. Genetic aspects of inflammatory bowel disease. Clin Gastroenterol 1973; 2: 555-73.

3 Mayberry JF, Rhodes J, Newcombe RG. Familial prevalence of inflammatory bowel disease in relatives of prevalence of inflammatory bowel disease in relat

4 Lobo AJ, Foster PN, Sobala GM, Axon ATR. Crohn's disease in married couples. Lancet 1988; i: 704-5.

Almy TP, Sherlock P. Genetic aspects of ulcerative colitis and regional enteritis. Gastroenterology 1966; 51: 757-63. and regional enteritis. Gastroenterology 1966; 51: 757-63.
Korelitz BI. From Crohn to Crohn's disease - 1979: an epidemiologic study in New York City. Mt Sinai $\mathcal{F}$ Med 1979; 46: 533-40

7 Rosenberg JL, Kraft SC, Kirsner JB. Inflammatory bowel disease in all three members of one family. Gastroenterology 1976; 70: 759-60.

8 Zetzel L. Crohn's disease in a husband and wife. Lancet 1978; ii: 583.

9 Craxi A, Oliva L, Di Stefano G. Ulcerative colitis in a married couple. Ital F Gastroenterol 1979; 11: 184-6. 
10 Kirsner JB. Later development of inflammatory bowel disease in the healthy spouse of a patient. $N$ Engl f Med 1982; 307: 1148 .

11 Purrmann J, Cleveland S, Miller B, Strohmeyer G. Crohn's disease in a married couple. Hepatogastroenterology 1987; 34: 132-3.

12 Dua $\mathrm{KS}, \mathrm{Mow}$ spouse. Scot Med F 1988; 33: 372-3.

13 Murray CJW, Thomson ABR. Marital idiopathic inflammatory bowel disease. Crohn's disease in a husband and wife. 7 Clin Gastroenterol 1988; 10: 95-7.

14 Whorwell PJ, Eade OE, Hossenbocus A, Bamforth J. Crohn's disease in husband and wife. Lancet 1979; ii: 186-7.

15 Whorwell PJ, Hodges JR, Bamforth J, Wright R. Crohn's disease in husband and wife. Lancet 1981; i: 334.

16 Rhodes JM, Marshall T, Hamer JD, Allan RN. Crohn's disease in two married couples. Gut 1985; 26: 1086-7.
17 Holmes GKT, Painter NS. Crohn's disease in married couples. Gut 1986; 27: 350.

18 Hershfield NB. Crohn's disease in a mother, father and son. Can Med Assoc F 1984; 131: 1190-3.

19 Van Kruiningen H, Colombel JF, Cartun RW, Whitlock R, Koopmans M, Kangro HO, et al. An in depth-study of Crohn's disease in two French families. Gastroenterology 1993; 104: 351-60.

20 Colombel JF, Dupas JL, Cortot A, Salomez JL, Marti R, Gower-Rousseau $\mathrm{C}$, et al. Incidence des Maladies Inflammatoires du Tube Digestif dans le Nord Pas de Calais et le départment de la Somme (1988). Gastroenterol Clin Biol 1990; 14: 614-8.

21 Reilly RP, Robinson TJ. Crohn's disease: is there $x$ long latent period? Postgrad Med f 1986; 62: 353-4.

22 Allan RN, Pease P, Ibbotson JP. Clustering of Crohn's disease in a Cotswold village. $Q \mathcal{F}$ Med 1986; 59: 473-8.

23 Aisenberg J, Janowitz HD. Cluster of inflammatory bowel disease in three close college friends. $\mathcal{F}$ Clin Gastroenterol 1993; 17: 18-20. 